\title{
Diplomatic Farmers: \\ Iowans and the 1955 Agricultural Delegation to the Soviet Union
}

\author{
Peggy ANn BRown
}

ON A BALMY SEPTEMBER EVENING in 1955, 1,500 people crowded into a high school auditorium in Sioux City, Iowa, to hear Whiting farmer Herb Pike describe his recent visit to the Soviet Union. Pike had been part of a 12-member U.S. delegation that had just spent 32 days traveling nearly 10,000 miles across the Soviet Union to inspect Soviet farms while 12 Soviet officials were touring U.S. farms. Pike's Sioux City talk was the first of more than a hundred lectures he would give over the next several years. Recalling the Soviets' friendly welcome, Pike assured his audience that he had seen neither starving people nor preparations for war-chief concerns of Americans fearful of Soviet aggression.

Under Josef Stalin's regime, few Americans had traveled to the Soviet Union since World War II. With the Soviet premier's death in March 1953, Soviet leaders, especially Communist Party chairman Nikita Khrushchev, had begun to promote a policy of "peaceful coexistence." As a result, more Americans were able to obtain visas. In 1953 and 1954, 101 private American citizens received permission from the Soviet government to travel to the Soviet Union; the number increased to several hundred in 1955, and by 1959 had climbed to 10,000. President Dwight Eisenhower viewed Soviet interest in exchange visits

THE ANNALS OF IOWA 72 (Winter 2013). (C) The State Historical Society of Iowa, 2013. 
favorably, but State Department secretary John Foster Dulles was reluctant to promote cultural ties, concerned that Soviets would have a propaganda advantage. ${ }^{1}$

More than Winston Churchill's "riddle wrapped in a mystery inside an enigma," the Soviet Union aroused fears of nuclear war and the spread of Communism. Soviet support for North Korea in the Korean War, coupled with Senator Joseph McCarthy's charges of Communist influence in the United States, continued to affect American opinion of the Soviets. Yet, as the massive, mysterious nation began to emerge from its self-imposed isolation, many Americans were eager to know and understand its people and policies.

The 1955 agricultural delegations were designed to contribrute to such mutual understanding. News reports of the agricultural exchanges, and lectures by Pike and his fellow delegates-including four Iowans-provided contemporary images of the Soviet Union. In speeches throughout Iowa and across the country, the delegates shared observations, opinions, and photographs and boasted that they had shown their hosts that Americans did not have horns - an expression Soviets had repeatedly used about themselves to welcome the delegation. Their talks offered firsthand insights on the closed country and helped generate more hopeful interest in the Soviet Union and its people, as did the simultaneous tour of U.S. farms by 12 Soviet officials. Historian Walter L. Hixson calls the 1955 agricultural delegations "a breakthrough in East-West exchange." 2 J. D. Parks adds that although "no one assumed ... that exchanging two dozen farmers was going to bridge the ideological gap separating the two nations ... . it was a start, and a promising one." 3

1. U.S. Department of State, Foreign Relations of the United States, 19551957, vol. 24, Soviet Union, Eastern Mediterranean, Document 94, NSC 5508/1, Statement of Policy on Admission to the U.S. of Certain European Non-official Temporary Visitors Excludable Under Existing Law, March 26, 1955, http:/ / history.state.gov/historicaldocuments/frus1955-57v24/d94; Irving R. Levine, Travel Guide to Russia (Garden City, NY, 1960), 13; Walter L. Hixson, Parting the Curtain: Propaganda, Culture, and the Cold War, 1945-1961 (New York, 1997), 103-5.

2. Hixson, Parting the Curtain, 104.

3. J. D. Parks, Culture, Conflict and Coexistence: American-Soviet Cultural Relations, 1917-1958 (Jefferson, NC, 1983), 145. 
THE IMPETUS for the agricultural exchange was a Des Moines Register editorial by Lauren Soth on February 10, 1955. Soth was responding to a January 25 speech by Nikita Khrushchev before the Central Committee of the Communist Party in which he had praised the U.S. feed-livestock economy. ${ }^{4}$ Khrushchev disputed studies that claimed that "only a narrow belt . . . of the Soviet Union was suitable for corn growing." He asserted that by increasing corn production in the Ukraine and elsewhere, and by launching the New Lands program in Kazakhstan and Siberia, the Soviets could increase feed for livestock, following the U.S. "corn-hog" model. 5

Writing in what he later called "an idle and somewhat sportive mood," Soth invited Russians to Iowa for "the lowdown," promising to hide none of the state's "secrets." 6 In turn, Iowans could visit the Soviet Union to share their farming know-how. Soth claimed no diplomatic authority but thought such visits had the potential to ease tensions. He doubted that either the Soviets or the U.S. government would allow such visits, even if they would make sense. To Soth's surprise, Khrushchev was interested. A Tass correspondent stationed in New York had cabled Soth's editorial, reprinted in the Christian Science Monitor on February 19, to Moscow. Two weeks later, Ambassador Charles Bohlen wired Secretary Dulles that Agriculture (the Soviet Union Ministry of Agriculture newspaper) supported the exchanges. ${ }^{7}$

Caught off guard the following day at a press conference, President Eisenhower responded affirmatively when asked if he supported a visit by Russians to inspect Iowa's corn and hogs.

4. Lauren Soth, "If the Russians Want More Meat," Des Moines Register, 2/10/ 1955; idem, "Let the Russians Come to Iowa," 3/2/1955.

5. "Soviet Plans to Copy U.S. Corn Economy," New York Times, 2/4/1955.

6. Lauren Soth, "A Little Editorial-Big Results," Lauren K. Soth Papers, RS 16/03/54, University Archives, Special Collections, Iowa State University Library, Ames (hereafter cited as Soth Papers). It was common practice in 1955 to refer to all residents of the Soviet Union as "Russians"; where this article refers to "Russians" (as in the March 2, 1955, press conference with Eisenhower below), that is the term that was used by participants.

7. Telegram, Bohlen to Secretary of State, 3/1/1955, Central Decimal File 032 (Tours), Dept. of State, Record Group 59, National Archives at College Park, College Park, MD (hereafter cited as NA). 
Reiterating his position that Russians did not want war any more than Americans, Eisenhower concluded that he "couldn't imagine anything better than to have ... their agricultural people visit our agricultural people." By asking the question, Fletcher Knebel, a reporter for Cowles Publications, the company that published the Des Moines Register, had compelled the president to end the official silence on the proposed Soviet visit. ${ }^{8}$

The State Department was less enthusiastic than Eisenhower about Soth's invitation. At the same time, Ambassador Bohlen warned that Soviet newspapers were labeling the State Department's reticence as proof that the real Iron Curtain existed in the United States, not in the Soviet Union. ${ }^{9}$ Given these circumstances, State Department officials advised that the time was psychologically ripe for an exchange, if the Des Moines Register agreed to sponsor the Soviets' visit and an exchange could be ensured. ${ }^{10}$

On March 10 the Soviet Ministry of Foreign Affairs formally requested the U.S. view of an agricultural exchange, citing its support. ${ }^{11}$ Behind the scenes, State Department officials worked to resolve the difficulties involved in such a project. When the Attorney General rejected the Des Moines Register as sponsor, the State Department approached Iowa State College (ISC), which agreed to help with technical arrangements. ${ }^{12}$ Finally, on

8. Eisenhower predicted entry problems for the Soviet visitors given current immigration regulations; the 1952 Immigration and Nationality Act, also called the McCarran-Walter Act, required fingerprinting of all private citizens from Communist countries. "The President's News Conference, March 2, 1955," The American Presidency Project, www.presidency.ucsb.edu/ws/?pid=10424. It is unknown whether Knebel ambushed the president on his own or at the Cowles' direction.

9. Telegram, Bohlen to Secretary of State, 3/3/1955, NA.

10. Memo, Robert Murphy to the Under Secretary re Visit to the United States of Soviet Corn-Hog Specialists, 3/8/1955, NA. Writing to an associate, Soth complained, "As I expected, the cautious boys in the State Department are carefully saying nothing and sounding as though they are afraid of the idea." Soth to Robert E. Kennedy, Chief Editorial Writer, Chicago Sun-Times, 3/3/1955, Soth Papers.

11. Translation of Soviet Note No. 21, 3/10/1955, NA.

12. James H. Hilton, president, Iowa State College, to John Foster Dulles, 3/31/1955, NA. In 1959 ISC became Iowa State University. To date, I have not been able to locate any information on why the Attorney General rejected the Des Moines Register as a sponsor. 
April 22, the State Department instructed the American Embassy in Moscow to inform the Soviets that a farm delegation could enter the United States during the summer. The one caveat was that the Soviet delegates must agree to submit to the fingerprinting required under U.S. law for non-official visits. ${ }^{13}$ Less than two weeks later the State Department revised its position on fingerprinting. Embassy staff had convinced Washington that, given the importance of the exchange, an alternative should be offered: if the Soviets were unwilling to comply with the U.S. policy, the government could authorize official visas and eliminate the need for fingerprinting. Eager to study U.S. farming firsthand, the Soviets agreed to send only officials, eliminating the need for fingerprinting but confirming American cynics' views that the Communist government would never allow real farmers to visit the United States. ${ }^{14}$

PUBLIC RESPONSE to Soth's proposal reflected the range of popular opinions on the Soviet Union, with Americans intrigued by or fearful of (or both) a visit by Communists. Newspapers across the country carried wire stories about the exchange, often reporting that Soth had originated the idea. Most commentators focused on the Soviet visit to the United States, mentioning the American delegation only in passing, if at all. Individuals soon queried government agencies for details and volunteered their services as delegates.

To some Americans, Khrushchev's praise of America's corn and hogs merely obscured the agricultural crisis facing the Soviet Union. To them, Soth's suggestion was thus irresponsible - sharing farm knowledge was akin to aiding an enemy who would become stronger and hence more of a threat. Although concerns over another world war-trending upwards since World War II-had dropped slightly by early 1955, 64 percent of Americans believed that there would be a major war with the

13. Telegram, Herbert Hoover Jr., Acting Secretary of State, to American Embassy, Moscow, 4/22/1955, NA.

14. See, among other communications, telegram, Walworth Barbour, Department of State, to the American Embassy, Moscow, 5/3/1955, NA. These arrangements saved the Soviets the need to protest the fingerprint requirement, which applied to citizens but not to government officials. 
Soviet Union "sooner or later." At the same time, more than half of respondents familiar with the Soviet term "peaceful coexistence" thought it was a good policy for the United States. In the two years since Stalin's death, many Westerners sensed a slight thaw in the Cold War. ${ }^{15}$

Soth's proposal reflected that optimism: knowledge of Iowa's good life, he wrote, "can only benefit the world and us. ... It might even persuade [the Soviets] that there is a happier future in developing a high level of living than in this paralyzing race for more and more armaments." 16 Soth and others repeatedly reassured naysayers that American agricultural expertise was already freely available to Soviets through journals and technical bulletins.

Newspapers and magazines weighed in on the value and feasibility of the exchanges. To the Washington Post, "an invitation to the Russian farmers, who have already indicated willingness to come, would seem to be imperative to enlightened diplomacy." The New York Times reflected on the Iron Curtain label flung at the United States by Soviets and advised admitting the farmers. ${ }^{17}$ The Des Moines Register proclaimed, "No Iron Curtain Needed Around Iowa," speculating that State Department underlings feared the taint of Communism should they support the tour. ${ }^{18}$

For Iowans, the debate had an immediacy that surpassed any abstract musings in the national press. The Soviets were coming to their towns, farms, and front porches. In the Marion Sentinel, former Cedar Rapids Gazette editor Verne Marshall complained of American gullibility, calling the proposal impressive "only to those who still believe the Communists will not bite the hand that feeds them." A week later Gazette publisher Ralph Young fired back that farmers might make better

15. George Gallup, The Gallup Poll: Public Opinion, 1934-1971, vol. 2, 1949-1958 (New York, 1972), 1300, 1304.

16. Soth, "If the Russians Want More Meat."

17. "Let the Farmers Come!" Washington Post, 3/3/1955; "Soviet-American Exchanges," New York Times, 3/4/1955.

18. "No Iron Curtain Needed Around Iowa," Des Moines Register, 3/4/1955. The fear was rooted in charges that "the State Department has been said to have been infiltrated by Communists," an obvious reference to Wisconsin Senator Joseph McCarthy's hunt for Communists. 
diplomats than Washington insiders and that a firsthand view of American freedom and standards could be a powerful incentive for change. ${ }^{19}$ For the Waterloo Courier, offering technical assistance to Soviet farmers was akin to providing strategic war materiel. Parsing the implications, it concluded that such assistance could be justified "only on the grounds that the more personal and friendly contacts there are among people the less the likelihood of war." The Cedar Rapids Gazette was similarly unimpressed. Blaming collectivization for destroying farmers' pride, it judged the visits futile until Soviets agreed to restore free enterprise. ${ }^{20}$

By April 29, Soth could count 42 editorials from across the country supporting his proposal and 4 against. In 113 letters-tothe-editor collected by Soth, the percentage of unfavorable responses was higher but still less than half. Out of 56 received to date from Iowans, only 16 opposed the exchange and 7 were neutral. ${ }^{21}$ Emotions ran high in the letters. Correspondents voiced concerns about the potential harm of allowing Communists into the country. To some, food was "as much a weapon as munitions." 22 The trip was called a propaganda trap, and Soth was variously dumb, naïve, or treasonous. Writers either worried about Soviet spies or advised others "not to be afraid of their own shadows." A national Gallup poll found that 62 percent of midwesterners thought a Russian delegation to the United States was a good idea, compared to 55 percent across the country; among U.S. farmers, support dropped to 49 percent. ${ }^{23}$

Eisenhower and the departments of State and Agriculture soon heard from constituents. Farmers from North Carolina, Texas, Washington, and Oklahoma, among other states, were eager to join the delegation. Most wrote directly to Dulles or

19. Verne Marshall, "Current Comment," Marion Sentinel, 3/17/1955; Ralph Young, "The Publisher's Notebook," ibid., 3/24/1955.

20. "Russians Eye Corn-Hog Cycle," Waterloo Courier, 3/15/1955; "They Won't Use Our Key," Cedar Rapids Gazette, 3/19/1955.

21. "April 29, 1955 Tally of Responses to Russian Farmer Exchange Proposal," Soth Papers. Soth does not identify the newspapers included in his count.

22. See, for example, L. S. Forrest, "Reader Opposes the Plan; Says Food Is a Weapon," Des Moines Register, 3/4/1955.

23. "The Gallup Poll: Russian Farmer Visits Favored," Washington Post, 4/17/ 1955. Gallup does not define the term midwesterner. 
Secretary of Agriculture Ezra Taft Benson, although some requests were passed on by members of Congress. By mid-May, State Department officials reported that the number of citizens expressing interest far exceeded the number of anticipated delegates. ${ }^{24}$ Protestors also chimed in, concerned about Soviets entering the United States. A petition signed by several hundred Cedar Rapids residents protested the potential for "espionage and ... endanger[ment]." A New Yorker worried that farm visits would be the "the perfect opportunity for them to leave us a legacy of bacteria which would ruin our crops and soils" and suggested instead sending technical materials "by the car load." 25

THE STATE DEPARTMENT repeatedly emphasized that the American delegation to the Soviet Union would have no official status. To underscore the point, the department announced that a nongovernmental committee would choose the delegates effectively removing itself from political pressure as well as the thankless job of sifting through letters. ${ }^{26}$

In early June the Agriculture and State departments asked land-grant colleges and national farm organizations to nominate potential delegates. ${ }^{27}$ Colleges were asked to identify their best candidates, detailing their qualifications and justifying their inclusion. Nominees should be competent in specific areas, such as wheat, corn, livestock, irrigated cotton, soils, agricultural machinery, or agricultural research. Additional qualifications included analytical ability; farming experience; good

24. "Many U.S. Farmers Ask to Make Trip to Soviet," New York Times, 5/14/ 1955. Reports of the number of applicants ran as high as 600 .

25. Marie Vitek, Cedar Rapids, Iowa, to Herbert Hoover Jr., 3/25/1955, NA; Diane Smith, Lynbrook, NY, to President Eisenhower, 4/1/1955, NA.

26. Telegram, Secretary of State to the American Embassy, Moscow, 5/19/1955, NA.

27. Nominations were solicited from the National Farmers Union, National Grange, National Council of Farmers Cooperatives, and the American Farm Bureau Federation. True D. Morse, Acting Secretary of Agriculture, to James Patton, president, National Farmers Union; Herschel D. Newsom, master, National Grange; Homer L. Brinkley, executive vice president, National Council of Farmers Cooperatives; and Charles Shuman, president, American Farm Bureau Federation, 6/3/1955, Foreign Relations 5, Entry 17, Record Group 16, National Archives at College Park, College Park, MD. 
physical condition; and being native-born American with "sober, mature, and well-balanced personalities." The yet-to-benamed selection committee would not discriminate on the basis of color, creed, or ethnic origin and was interested in "various age groups from different economic strata." Nevertheless, because the trip would be unofficial, delegates would be expected to pay their own costs, estimated at the time at $\$ 2,500$ (approximately $\$ 20,000$ in today's dollars). ${ }^{28}$

Three weeks later the Agriculture Department (USDA) announced the selection committee: J. Stuart Russell, farm editor, Des Moines Register; Homer L. Brinkley, executive vice president, National Council of Farmer Cooperatives, Washington, D.C.; and Russell I. Thackrey, executive secretary, Association of LandGrant Colleges and Universities, Washington, D.C. They met in Washington, D.C., on June 21 and 22 to make their selections. Soth had already begun lobbying the Agriculture Department for an all-Iowa contingent. His editorial had specifically suggested sending Iowa farmers, and he believed the exchange could be a showcase for ISC faculty. ${ }^{29}$

On June 22 the State and Agriculture departments jointly announced the delegation. The committee selected Soth; Herbert W. Pike, farmer, Whiting, Iowa; John Marion Steddom, farmer, Grimes, Iowa; Ralph Ainslee Olsen, farmer, Ellsworth, Iowa; Charles J. Hearst, farmer, Cedar Falls, Iowa; W. V. Lambert, dean of the College of Agriculture, University of Nebraska; D. Gale Johnson, associate professor of agricultural economics, University of Chicago; Asa V. Clark, farmer, Pullman, Washington; Ferris Owen, farmer, Newark, Ohio; John M. Jacobs, farmer, Phoenix, Arizona; and J. M. Kleiner, distributor of agricultural products, Nampa, Idaho. Despite the apparent geographical diversity of the selected delegates, five resided in

28. News Release (6/2/1955) and Draft Memo (6/1/1955) from Cannon C. Hearne, Director of Foreign Training, Foreign Agricultural Service, to College Contacts (Deans) on Foreign Agricultural Affairs, Soth Papers. A similar document in Charles J. Hearst Papers, MS 3, Special Collections, Iowa State University Library, Ames (hereafter cited as Hearst Papers), mentions the desirability of geographic diversity and Russian language ability.

29. Lauren Soth to Gwynn Garnett, Director, Office of Foreign Agricultural Relations, USDA, 6/1/1955, Soth Papers. 
Iowa and four more had an Iowa connection by birth, education, or both. With international experience and past service as the Department of Agriculture's research director, Lambert was appointed to lead the delegation. ${ }^{30}$

The five Iowa delegates had spent most of their lives in the state. Soth, age 44, had been born in Sibley. After earning a bachelor's degree in agricultural journalism from ISC in 1932, he taught at the college for 14 years and received a master of science degree in agricultural economics in 1938. Soth served as an army major in Korea and the Philippines during World War II. By 1955 he had been working as an editorial writer for the Des Moines Register for seven years and had been promoted to editor of the editorial pages the previous year. ${ }^{31}$

Charles Hearst had already participated in one international agricultural mission. In 1947 he had toured Europe with an Iowa Farm Bureau group investigating the food situation and the Marshall Plan's potential to address war-torn countries' needs. ${ }^{32}$ Hearst, 51, lived near Cedar Falls all his life, farming Maplehearst, the family's 580-acre cattle-hog farm. He graduated from Iowa State Teachers College and had served as county Farm Bureau president and a member of the county board of education.

After graduating with a degree in animal husbandry from ISC in 1923, Ralph Olsen returned to his hometown of Ellsworth to raise hogs and cattle on 940 acres. Olsen, 54, was an active proponent of cooperatives. In 1955 he was director of a local grain marketing cooperative and president of both a regional cooperative soybean processing association and the Iowa Institute of Cooperatives. ${ }^{33}$

30. State Department Press Release, 6/22/1955, NA. The committee did not select any women for the delegation despite female applicants and support for their inclusion by Farm Journal women's editor Gertrude Dieken. Farm Journal, 3/26/1955.

31. The June 22, 1955, joint news release provided brief biographical statements on each of the delegates. Additional information on Soth is from Current Biography 1956 (New York, [1956?]), 594-95.

32. "Farm Group Backs Aid-to-Europe Idea," New York Times, 9/2/1947; "Food as 'Weapon' For Peace Urged," ibid., 12/16/1947.

33. Frank Robotka, ISC, to J. K. Stern, American Institute of Cooperation, 6/14/ 1955, Ralph A. Olsen Papers, RS 21/7/55, Special Collections, Iowa State University Library, Ames (herafter cited as Olsen Papers). 


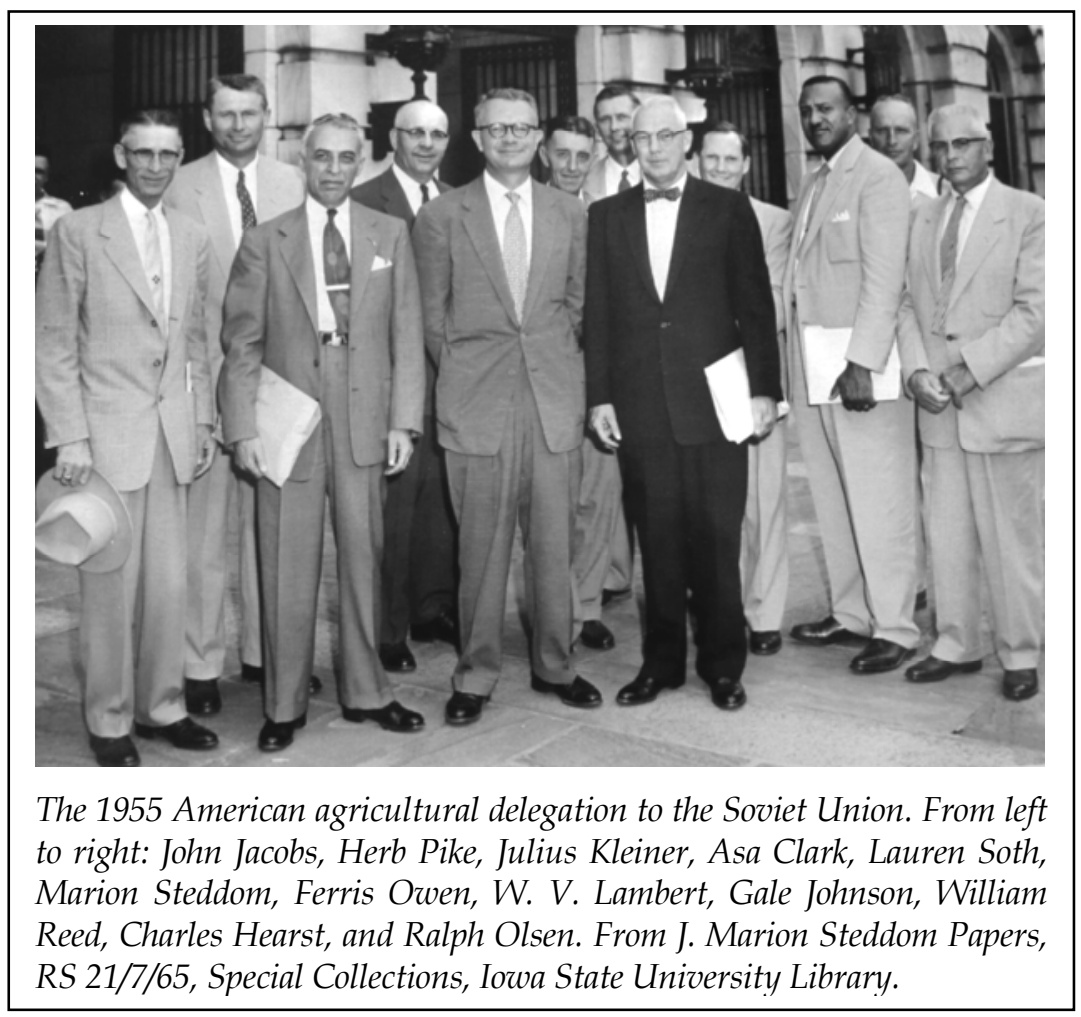

Also a leader in farm organizations, delegate Marion Steddom, 53, raised a thousand hogs per year on his 400-acre farm near Granger. Steddom had been named an Iowa Master Swine Producer in 1943 and was president of the Iowa Swine Producers Association. In 1922 he had completed a two-year agricultural course at ISC. He had spent seven years working for the USDA on barberry eradication in Iowa. ${ }^{34}$

Whiting native Herb Pike farmed 700 acres of the family farm, producing corn, hogs, and soybeans. Pike, 44, had studied at ISC, earning a bachelor's degree in agriculture (1933) and a

34. The State Department announced Steddom's inclusion in a separate news release "due to a delay in getting his confirmation." State Dept. Press Release, 6/24/1955, NA. See also Herb Plambeck, "J. M. Steddom . . . Master FarmerMaster Pork Producer," Wallaces' Farmer, 3/8/1980, photocopy in J. Marion Steddom Papers, RS 21/7/65, Special Collections, Iowa State University Library, Ames (hereafter cited as Steddom Papers). 
master's degree in economics (1939). Before his stateside service in World War II, he had worked as a farm manager and an insurance company appraiser. Like Steddom, he had earned distinction as an Iowa Master Swine Producer. ${ }^{35}$

The Iowa connection ran strong among the other delegates. D. Gale Johnson, 39, the University of Chicago professor, had been born in Vinton. Both his bachelor's and doctorate degrees in agricultural economics were from ISC, where he had taught from 1938 to 1944. Arizonan John Jacobs, who turned 58 during the tour, was originally from Johnson County, Iowa; and Lambert had taught genetics at ISC from 1923 to 1936.

On July 6, the USDA announced the final delegate, William E. Reed, 43, dean of the School of Agriculture at North Carolina Agricultural and Technical College in Greensboro. A Louisiana native, he had earned a master's degree in soils science at ISC in 1941 (and a doctorate from Cornell University). Reed was the only African American delegate. By 1955 he had served as a Foreign Service Officer in Liberia. ${ }^{36}$

The delegates had less than a month to prepare for their July 12 departure. The farmers in the group finished midsummer chores and made arrangements for the rest of the season. Delegates applied for passports and Soviet visas. Lambert flew to Washington to finalize the itinerary while delegates debated which type of camera was best and whether they would even be allowed to take photographs (they were).

On July 11 and 12 the delegation gathered in Washington for briefings with officials from the State and Agriculture departments. While such discussions were not unusual for international travelers, a news conference was out of the ordinary, as was the vodka toast at the Soviet embassy - the latter a fore-

35. Monona County, Iowa: Monona County History (1982), 371.

36. Agriculture Department, Press Release, 7/6/1955, Hearst Papers. Reed's inclusion was most likely the result of a conversation between American Embassy Chargé d'Affaires W. N. Walmsley and African American journalist William Worthy, who was visiting Moscow. Worthy recommended that the delegation include a Negro, as he was often asked about the "race problem" in the United States; Telegram, Walmsley to Secretary of State, 6/28/1955, NA. As dean of a land-grant college, Reed had nominated a local Farm Bureau employee, but the committee instead asked him to participate. Interview by D. W. Colvard, 2/14/1980, William and Mattye Reed Collection, Smithsonian National Museum of African American History and Culture, Washington, DC. 
shadowing of what soon would become routine. Pledging that the delegates would keep their eyes and minds open and their "ears unplugged," Lambert listed the delegation's goals for reporters. Its primary objective was to evaluate Soviet agriculture -its progress, techniques, potential, research, and marketing. The remaining goals - meeting and sharing with Russian farmers and planting "a few seeds of understanding and good will" - would become equally important. ${ }^{37}$

In Washington the group was joined by two journalists. The State Department had originally argued that reporters' presence might restrict American access. Reporters wanted in, however, and NBC broadcaster Irving R. Levine forced the issue. Levine prowled the halls of the State Department, determined to get approval. Stonewalled, he sent a telegram to Khrushchev; the party chairman okayed his visa before State had even authorized the exchanges. Once Levine's success was known, the State Department approved Moscow-based correspondents from the New York Times, the International News Service, and the United Press, and the Soviets acquiesced. ${ }^{38}$

The second U.S.-based journalist was farm broadcaster Herbert Plambeck from WHO-Des Moines. In May Plambeck had begun lobbying the State and Agriculture departments to be included in the delegation. Disappointed to be excluded, he applied for a visa as a correspondent. On July 7, he wrote in his journal that he had "given up on the idea," but the next day recorded a hectic schedule as he learned that his visa had at last been approved. ${ }^{39}$ (Soth, who wrote occasional articles during the trip, participated as a delegate and waited until after the tour to prepare in-depth commentaries.)

On July 12 the twelve delegates - plus Levine and Plambeck - traveled to New York to catch a flight to London. From there they flew to Helsinki and then on to Moscow for the start

37. "Farmers List Objectives of Russians Visit," Cedar Rapids Gazette, 7/13/1955.

38. Moscow-based American reporters covering parts of the tour were Charles Klensch (International News Service), Kenneth Brodney (United Press), and Welles Hangen (New York Times).

39. Herbert Plambeck, Journal, Herbert Plambeck Papers, RS 21/7/42, University Archives, Special Collections, Iowa State University Library, Ames (hereafter cited as Plambeck Papers). 
of their 32-day tour. Arriving in the Soviet capital, they spent a few days visiting the usual tourist sites: the All-Union Agricultural Exhibition, Bolshoi Ballet, and a nearby collective farm. Over the next five weeks, the delegates would visit Soviet regions that had been closed to Westerners for more than a decade.

THROUGHOUT MAY AND JUNE, U.S. and Soviet officials had negotiated the Americans' itinerary in the Soviet Union. The American delegates wanted to visit the Ukraine, the Kuban, Uzbekistan, and the new lands area of Kazakhstan and western Siberia, and the Soviets agreed to include those regions in the itinerary. The Soviets also gave permission for Horace J. Davis, an economic officer and agricultural specialist at the American embassy in Moscow, to accompany the group. (Prior to the delegation's tour, Davis had seen only one farm, a collective near Moscow.) Soviet officials repeatedly assured the embassy that delegates would be allowed to see what they wanted to see.

With Intourist, the Soviet travel agency, making transportation and accommodation arrangements, embassy staff requested enough surface travel to allow close observations. Background briefings had familiarized delegates with the differences between the state and collective farms and machine tractor stations they would visit. In 1955 the Soviet Union had 89,000 collective farms, averaging 15,300 acres each. Created from consolidated estates and peasant farms after the 1917 Russian Revolution, the collective farms paid workers based on the success of crops; equipment was shared by neighboring collective farms and stored and maintained by the country's 9,000 machine tractor stations. The 5,000 state farms averaged 38,100 acres and paid workers a flat salary. ${ }^{40}$

On the evening of July 18, the delegates left Moscow by train for the eastern Ukraine. Arriving at Kharkov in the early afternoon, they were met by several thousand cheering residents. Lambert greeted the crowd with words that would be repeated throughout the tour: "This exchange of delegations is the beginning of stronger friendship and an interchange of ideas between

40. "The Farm System in the Soviet Union," attachment, Horace J. Davis, Attaché, American Embassy, Moscow, to John M. Steddom, 9/15/1955, Steddom Papers. 


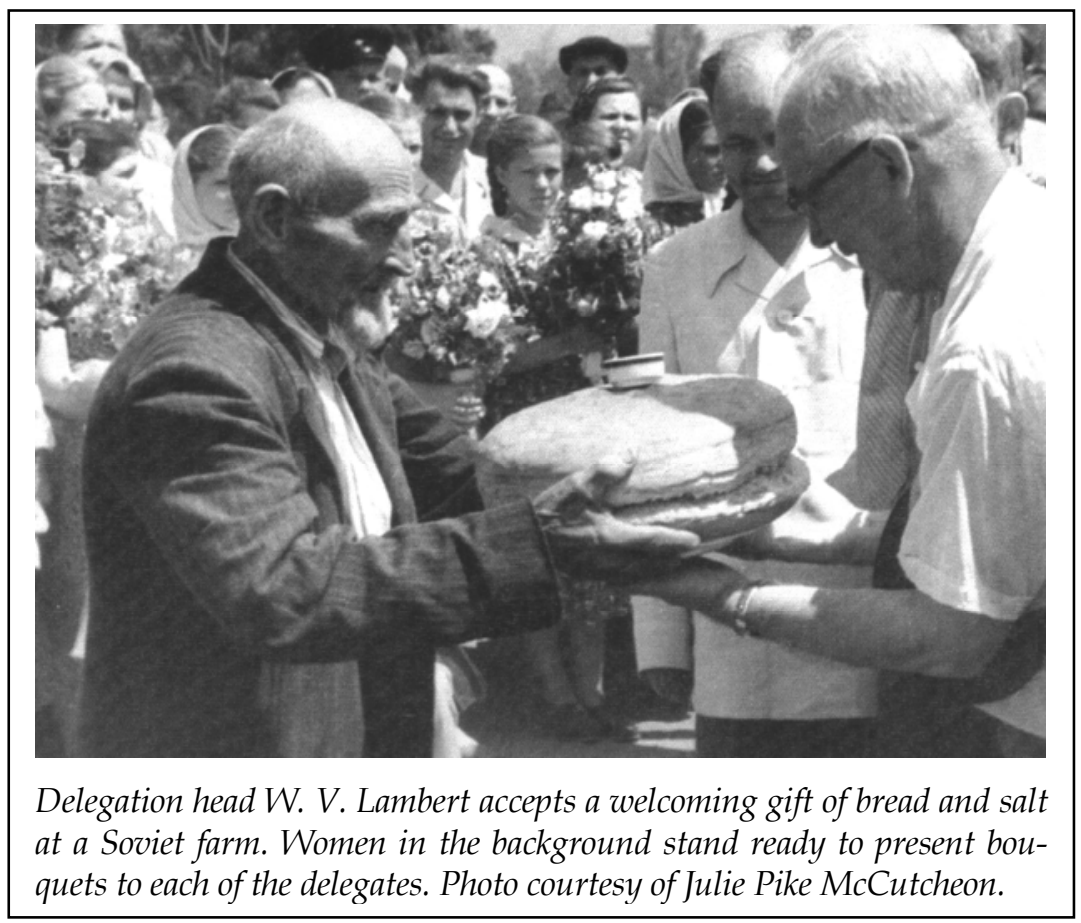

our two great countries." 41 Delegates began the pattern they would follow in each region: visits to state and collective farms as well as to a factory, park, or research institute. Everywhere they went friendly crowds shouted warm greetings and pressed close to see their first Americans.

At the Lenin's Course Collective farm outside Kharkov, women farm workers gave delegates floral bouquets, a friendly gesture that proved mandatory at each of the nearly three dozen farms the delegates visited. Opening ceremonies often included the presentation of a salt cellar and a loaf of bread, traditional welcoming gifts for important guests. While look-alike bouquets and oversized bread loaves indicated that the gatherings might be less than spontaneous, the delegates and other western observers believed that the friendly curiosity was genuine. ${ }^{42}$

41. "Russians Cheer U.S., Kharkov Greets Americans with Heroes' Welcome," New York Times, 7/20/1955.

42. After a similar welcome outside Krasnodar, Levine observed workers climbing into trucks for the 30-mile trek back to their factory; he concluded 
The delegates proved courteous guests, sitting down to massive meals and toasting peace, friendship, their hosts, and even reporters. The Soviets often provided mealtime entertainment. Perhaps not surprisingly after a dozen toasts, the hosts and guests serenaded each other-the Soviets singing the "Volga Boatmen" and the Americans offering "Home on the Range" and the "Iowa Corn Song." Despite hours spent socializing, the delegates took detailed notes on each of the farms and research institutes they visited.

Their next stop was the Dnieper River hydroelectric station near Zaporozhe and a look at farms irrigated by the plant. The delegates then flew to Odessa, a northern Black Sea port. Arriving in a storm, they were thanked by the welcoming party for bringing the rain, a worker adding, "This will help our harvest, and I mean corn." 43

In Odessa the group spent several hours at the All-Union Lysenko Institute of Plant Selection and Genetics. The Americans linked Trofim Lysenko's theories on heredity to Soviet difficulties to produce hybrid corn varieties. Lysenko had argued that heredity could be altered by "educating the plant" to grow in a new environment, thus allowing certain species to become more suitable to Soviet conditions (a view that meshed well with Stalin's theories). Although Lambert thanked the institute for its "important research," he told staffers that U.S. botanists had rejected these theories. ${ }^{44}$

On the 8,500-acre Budenny Collective Farm outside Odessa, the delegates inspected their first workers' homes. The small sandstone buildings were clean and neat but lacked floors or in-

that their enthusiasm was genuine even if their appearance was not impromptu. Script draft beginning "The unique tour of the American farmers," undated, Irving R. Levine Papers, Manuscript Division, Library of Congress, Washington, DC.

43. Welles Hangen, “Americans Cruise Dnieper," New York Times, 7/24/1955. A year later, Hangen would be expelled from the Soviet Union ostensibly for taking photos of the same dam that the American delegates had photographed. "Soviet Union Orders Times Man Expelled," New York Times, 11/20/1956.

44. Welles Hangen, “Lysenko Theories Used," New York Times, 7/27/1955; "American Delegation Visits Around Odessa,"Baltimore Sun, 7/27/1955; Lauren Soth, "Soviet Farm Research Is Bent to Fit Theories," Des Moines Register, 8/26/1955. 


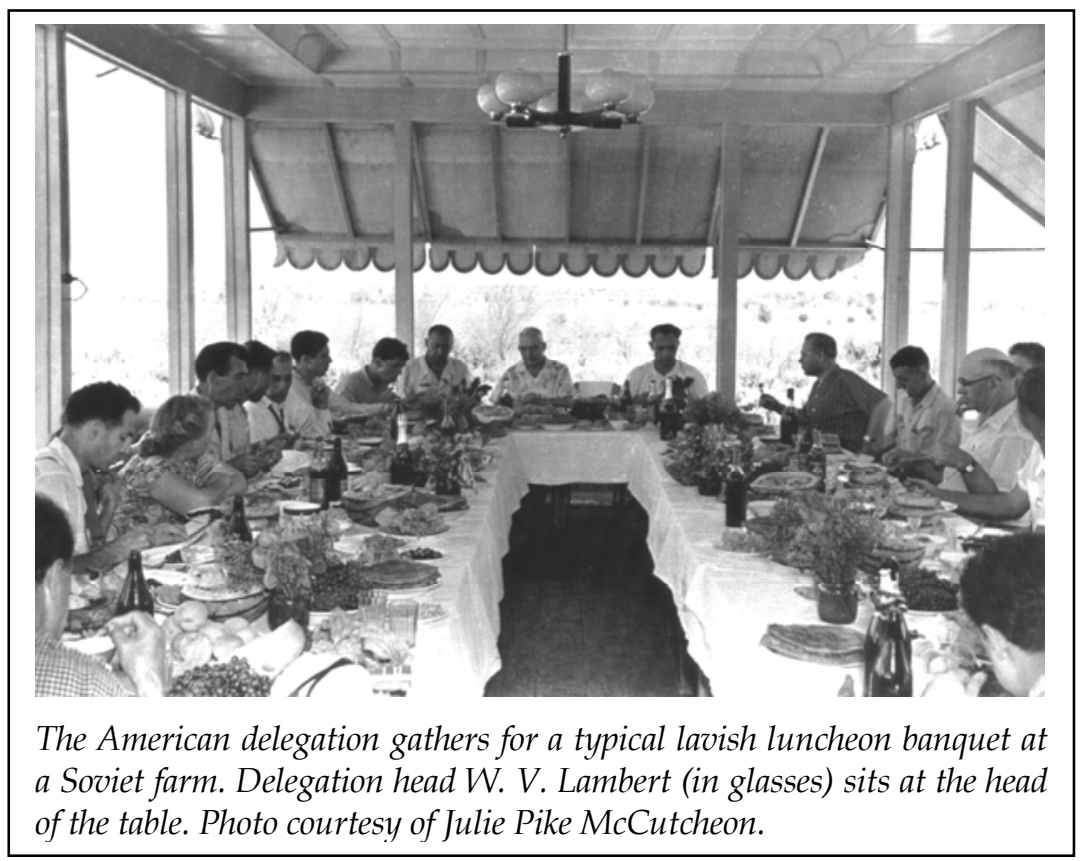

door plumbing. After a big midday meal, they visited a family who proudly displayed their home. Because the women had prepared dinner, the delegates felt obligated to eat again. They then returned to Odessa for a farewell meal presented by the Ukrainian Ministry of Agriculture. 45

The unrelenting hospitality began to take its toll. The combination of too much food and alcohol caused upset stomachs that confined some delegates to their hotel rooms. The lengthy midday meals also cut into the time available to inspect the farms. Joking at first about expanding waistlines, delegates soon complained to the Soviet officials accompanying the tour. ${ }^{46}$

45. Ralph Olsen to Genevieve, Blanche, Neil, and Etta, 7/27[?]/1955, Olsen Papers.

46. Olsen's recitation of a Ukrainian dinner is typical: "caviar from sturgeon and salmon, two kinds of sardines and three other kinds of fish, cold roast beef, chicken, cheeses, tomatoes, cucumbers, hard-boiled eggs, onions, two kinds of bread, butter ... pastry with ground beef . . clear hot soup . . . broiled beef filet and small buttered potatoes . . . ice cream and a fancy three-layer burnt sugar cake." Ralph Olsen, "Here's Bill of Fare that Faced Americans in Russia," Cedar Rapids Gazette, 8/3/1955. 
A reprieve from the excessive banqueting came as the delegates sailed across the Black Sea from Odessa to Novorossisk. Along the way they stopped at Yalta, site of the 1945 meeting between Stalin, Churchill, and Roosevelt. There they spotted anti-American billboards depicting Uncle Sam ready to wage atomic warfare, which the Soviets nervously allowed them to photograph. Ten thousand cheering people jammed the docks at Novorossisk as the delegation tried to disembark. The delegates conceded that they were beginning to feel "more like heroes than plain dirt farmers." The group was intent on focusing on the farms and avoiding the prolonged meals, which were estimated to have taken up a third of their time. ${ }^{47}$

Treated to another lengthy lunch-complete with champagne-at a vineyard near Novorossisk, the delegates were in no mood for another grape farm the next day. As Horace Davis reported later, the Soviets always gave excuses for why itinerary changes were impossible. On July 31, Soth and Johnson faced down their Soviet handlers, determined to choose which farms they would see. They were finally allowed to split into two groups - one going to the champagne vineyard and the other allowed to make two unscheduled visits to farms between Novorossisk and Krasnodar. Their surprise forays revealed farms less successful than the others they had toured. ${ }^{48}$ At Krasnodar, a crowd estimated at 10,000-20,000 met the delegation. They again split into two groups to maximize their observations.

As the group explored farms in the North Caucasus foothills area, agriculture took priority, with the delegates happily munching sandwiches between visits. Freed from the niceties imposed by previous farms' hospitality, they began to ask more questions and speak freely about the shortcomings they witnessed. Observations often focused on the farms' large workforces. To farmers used to working the land with the aid of one

47. Kenneth Brodney, "Russians Greeting Touring U.S. Farmers Like Heroes," Cedar Rapids Gazette, 7/30/1955; "Yanks Tire of Vodka, Get Champagne," Chicago Daily Tribune, 7/31/1955.

48. Foreign Service Despatch, Horace Davis Report 1 on the U.S. Agricultural Delegation's Tour of the Soviet Union, 11/22/1955, NA; "Americans in Soviet Rebel at 'Too Much Food, Drink,'" Cedar Rapids Gazette, 8/1/1955; Welles Hangen, "Americans Rebel at Banquets, Make Foray to 2 Soviet Farms," New York Times, 8/1/1955. 


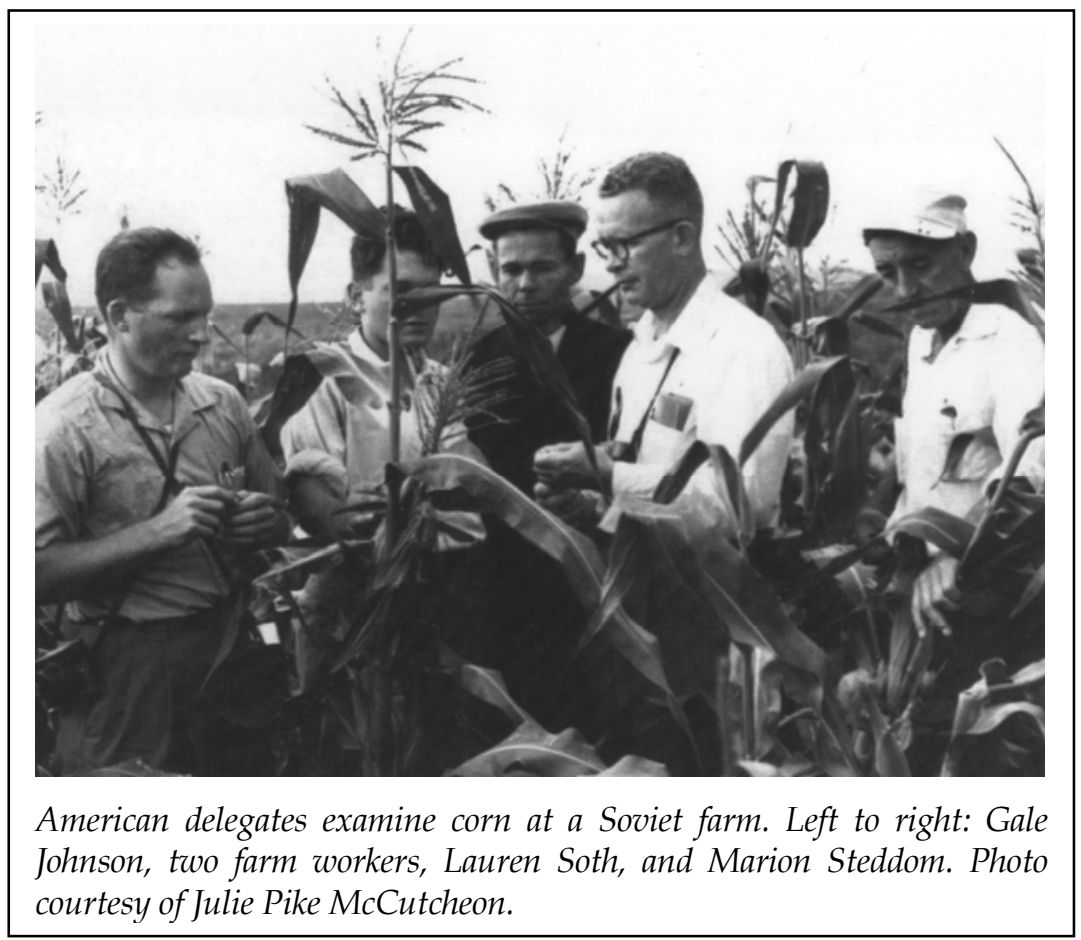

or two hired men, the sight of dozens of workers in the fields proved curious. They were also both amazed and disturbed by the large number of women engaged in heavy labor on farms and in factories. 49

After visiting Stalingrad and farms in the Volga Valley region, the delegation flew to central Asia. Near Tashkent, Uzbekistan, they visited irrigated cotton farms just 200 miles from China's border. With their tour coming to an end, the group flew to Alma Ata in Kazakhstan. Despite efforts to shorten time in the western regions to allow for more study of the new lands, the delegates were allotted only a few days there. One group explored farms in Akmolinsk, while the other headed to Rubisovsk in Siberia, where the delegates likened workers to

49. Plambeck reported that at least 60 percent of the farm laborers they had seen were women, owing both to labor policies and the loss of working-age men during World War II. Herb Plambeck, "U.S. Visitors to Soviet Union See Many Women Laborers," Christian Science Monitor, 8/17/1955. 
America's western pioneers. While voicing concerns about the area's climate and low rainfall, the delegates concluded that the virgin lands could produce the grains crops Khrushchev desired.

The flight back to Moscow was more than 1,300 miles. There the delegates presented their observations and recommendations to Soviet agriculture officials. Among their concerns was the excessive use of farm labor and lack of incentives for workers. Specific suggestions included planting sorghum and legumes rather than corn in areas of insufficient rainfall, and using terracing and contour plowing to combat erosion. Rural adult education, particularly for women, was stressed as a means to improve living conditions and family and home management. Not surprisingly, the delegates encouraged future exchanges of farmers, scientists, technical specialists, and students. ${ }^{50}$

Soth also reiterated the delegates' grievances. Sweetening his criticisms, he complimented Soviet hospitality and arrangements that had allowed them to see the country's major agricultural regions. Soth again complained about the fixed schedule. He reminded the officials that they had failed to provide the promised statistical information necessary to better appraise the visited farms as part of the whole system. One petulant Soviet official claimed that the tour was not an "ironclad one that you had to follow blindly." Speaking extemporaneously, the minister of state farms offered a few rough agriculture statistics, admitting that 1955 's grain harvest was expected to fall short of its goals. He accepted the Americans' criticisms and promised that if they returned in two years "they would find that many of their suggestions had been implemented." 51

After visiting 25 collective farms, 9 state farms, 4 machine tractor stations, 2 hydroelectric plants, and assorted factories and research institutes, the delegates were ready to head home. They had gathered information on Soviet agriculture in regions usually off limits to Westerners and had successfully served as goodwill ambassadors.

50. Welles Hangen, “Soviet Discloses Secret Farm Data," New York Times, 8/21/ 1955; Horace J. Davis, reporter, "The U.S. Agricultural Delegation's Tour of the Soviet Union. VI. Notes on Miscellaneous Agricultural and Non-Agricultural Installations Visited," Foreign Service Despatch from American Embassy, Moscow, to the Dept. of State, 3/23/1956, NA.

51. Ibid. 
AS THE AMERICANS concluded their journey, the Soviet officials' U.S. tour was also winding down. Their travels had taken them from Iowa to Nebraska, South Dakota, Minnesota, Illinois, Michigan, and California. Headed by First Deputy Minister of Agriculture Vladimir M. Matskevich, the group included experts in economics, scientific research, and farm machinery, as well as officials representing state and collective farms and machine tractor stations. They were - in the words of New York Times reporter Harrison Salisbury, recently returned from six years in Moscow - some of the "most influential men in the Soviet Union." 52

ISC officials were determined to show the Iowa way by taking the Soviets to family farms. For two weeks, the Soviet delegation toured farms around the state. They ate meals with farm families, inspected their fields and livestock, and, in Jefferson, slept in families' homes and attended their churches.

Unspoken parallels between the delegations appeared in the press - as much a factor of human nature as journalistic zeal. Curious, cheering crowds met the visitors. Charles Hearst tried out a tractor in Pereshchepino while Aleksandr Ezheviski drove one in Polk County. The "Iowa Corn Song" and "Volga Boatmen" were heard in the Ukraine and in Cedar Rapids. Russians tried on Indian headdresses in South Dakota; Americans modeled silk robes in Kazakhstan. Meals were a central motif in stories of both delegations: in the United States, picnic suppers of fried chicken, mashed potatoes, and lemonade replaced the lavish banquets washed down with vodka served to the American delegates.

Differences emerged, too. Obliging guests, the Soviets could change their schedules at will and break off on separate expeditions. American journalists outnumbered the Russian delegates eight to one in Iowa; only five reporters followed the Americans in the Soviet Union, although the group's numbers swelled with Soviet press, officials, interpreters, and Intourist staff.

Throughout their stay Soviets commented on American friendliness and hospitality. Unlike their counterparts, they came face-to-face with protestors - one picketing their visit, another protesting Iowa racism - their presence reinforcing the freedoms the Soviets' hosts were heralding. Likewise, the absence of State

52. “Who They Are," Des Moines Register, 7/19/1955. 


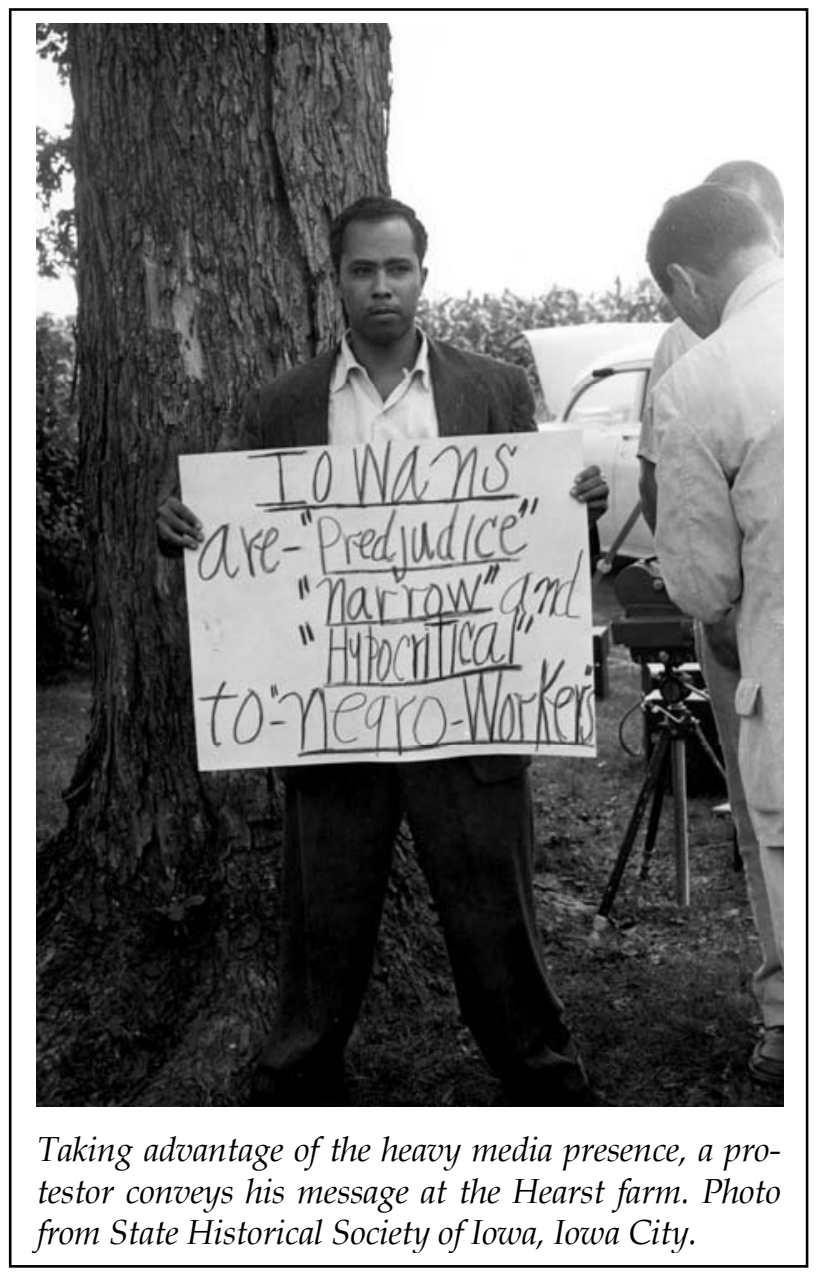

and Agriculture department employees - with the exception of interpreters who were, unfortunately, unfamiliar with agricultural terms - underscored the independence of American farmers.

Matskevich later commented in a Soviet journal that the Soviet officials had come to learn about hybrid corn, machinery, and livestock production. Delegates saw practices they would apply to Soviet agriculture, such as hybrid seed and hog production and labor-saving devices. Declining to detail American shortcomings, he attributed U.S. advances to its escape from the ravages of war. What made the deepest impression, he said, 
were the farmers and researchers themselves: "ordinary men and women of America who want peace ... to pool experience, to do business." 53

THE AMERICAN DELEGATES returned home as minor celebrities. Wire service reports had ensured that their photos, stories, and quotes would run in both national and small-town newspapers (often coupled with news of the touring Soviets). Fresh from their trip, Ralph Olsen and Gale Johnson appeared on the televised American Forum, interviewed by then Assistant Secretary of Agriculture Earl Butz and Hershel Newsome of the National Grange. Lambert was grilled on Meet the Press. The top story was the delegates' finding that there was no agricultural crisis in the Soviet Union. Reporters questioned the validity of such a conclusion based on a short guided tour; the delegates remained steadfast in their assessment. They also acknowledged their primary role as goodwill ambassadors. Pike endured an in-depth inquiry by U.S. News and World Report interviewers, whom he met in Berlin before returning home. The September 19 issue of Life ran an eight-page feature on the exchanges, including delegates' photos and Lambert's critique. ${ }^{54}$

During the tour, several Iowans had sent home dispatches describing their adventures. Affiliating with wire services offered a way to begin to recoup the tour's high costs, which ultimately averaged \$3,000 per delegate. Hearst reported for the Associated Press, earning $\$ 300$ for two stories. Pike authored his own stories during the tour for KVTV in Sioux City, sending letters and Polaroid pictures by airmail to the station. ${ }^{55}$

Once home, the delegates were swamped with lecture requests. Talks included their slides of the tour, supplemented by

53. "Vladimir Matskevich on American Agriculture," News - Soviet Review of World Events, 11/1/1955, translated in Foreign Service Despatch from the American Embassy, Moscow, to the Dept. of State, 11/12/1955, NA.

54. "What's Wrong with Russia's Farms as an American Farm Expert Saw It," U.S. News \& World Report, 9/2/1955, 28-31, 80-89; "How to Ease Russia's Food Crisis," Life, 9/19/1955, 164-71, including Lambert's assessment, "The Chief U.S. Delegate."

55. Cy Douglas, Chief, AP Des Moines Bureau, to Hearst, 7/1/1955, Hearst Papers; Scrapbook, "Window on the West, the Herbert Pike Lectures sponsored by KVTV," Pike Papers. 
photographs and a film provided by the Soviets. Lambert distributed a film produced by the University of Nebraska that he sometimes used in lieu of personal appearances. As private citizens, the delegates could speak their minds, using their own experience, education, and knowledge to interpret what they had seen. The State Department distributed background information but did not try to directly influence what the delegates reported. Lest the delegates forget, however, State Department fact sheets repeatedly stressed that the Communist Party dictated all policies as the Soviet Union's "master, teacher, and supervisor." 56

Everyone-local farm bureaus, colleges, churches, Kiwanis and 4-H clubs, state and national associations - wanted to hear from the delegates. Altogether, the Iowa delegates presented more than a thousand lectures over the next several years. Their schedules reveal nearly daily entries for speeches around Iowa and into neighboring states. The delegates assured listeners that they saw no impending food crisis or preparations for war. Emphasizing their friendly reception, they showed slides of the people and farms and explained how Soviet agriculture functioned.

"Communism seems to be working for them even if I don't like it," declared Marion Steddom on his return home. As head of the Iowa Swine Producers Association, Steddom was in high demand with swine farmers and county and state associations. By July 1956, he had given 168 lectures in 16 states. In his journal, Steddom had reflected on the damage war had done in the Soviet Union and its impact on the Soviet people. On July 27 he wrote, "Wherever we go in Russia the same questions by the man on the street, do you think there is going to be another war? War has an even more terrible meaning for the people of Russia than it has for the people of [the] United States (if that is possible). War has been a reality. Cities blown to pieces, whole communities evacuated. People leaving all their personal possessions to the invaders. Families separated and perhaps never reunited." 57

56. "The Union of Soviet Socialist Republics," attachment with letter from Horace J. Davis, Embassy Attaché, Moscow, to John M. Steddom, Granger, Iowa, 9/15/1955, Steddom Papers.

57. Allan Hoschar, "Gives Views on His Visit to U.S.S.R.," undated/unattributed newspaper clipping, Steddom Papers; Marion Steddom to the Internal Revenue Service, 7/25/1956, Steddom Papers; Marion Steddom, Journal, pages following 7/27/[1955], Steddom Papers. 
Unashamedly opening his lectures with "a little flag waving," Ralph Olsen spoke of his gratitude at being an independent farmer and for having the opportunities he and his audience shared. Olsen reported that curiosity had driven his decision to participate; he would have given his right arm to participate but "instead saved his arm and paid \$3,000." In his American Forum appearance, Olsen reiterated that the Russians did not have a current food shortage. He spoke admiringly of the Soviet education system's ability to easily disburse information to young people, although he assured his interviewers that he was not enthused by its other aspects. As he became further removed from his interaction with the Soviet people, Olsen became more critical. Describing the individual plots of land provided to farmers, he reported that many did not take advantage of them - either from transportation difficulties, time constraints, or because "the workers are just plain lazy." 58

Another prolific speaker among the Iowa delegates was Charles Hearst. His wife, Gladys, fielded invitations during his absence, notifying correspondents that September lectures had been scheduled before he left; by September, he was booked through February. Hearst's audiences ranged from Iowa farm bureaus, Rotary clubs, and extension offices to the U.S. Chamber of Commerce World Affairs Forum and an agricultural meeting of the American Bankers Association. A member of the chamber's Foreign Policy Committee, he spoke of his concern that the small Communist Party could dictate policy when so many people were friendly toward America. "Of course the places we visited were carefully selected and advanced preparations made," lectured Hearst. "But no government, no matter how tyrannical or despotic can order and get the kind of friendly curiosity ... that we received so often." He detailed farms they visited - with particular attention to the corn crops - as well as workers' assignments, salaries, and housing. ${ }^{59}$

58. Ralph Olsen, “Tulsa Talk 1955," Olsen Papers; Transcript, The American Forum, "Farming in Russia," 9/4/1955, Olsen Papers; Ralph Olsen, Speech transcript, untitled, begins "I would like to give you my impressions ...", Olsen Papers.

59. Charles Hearst, "Russian Trip," with notation "typescript copy of the handwritten speech," Hearst Papers. 


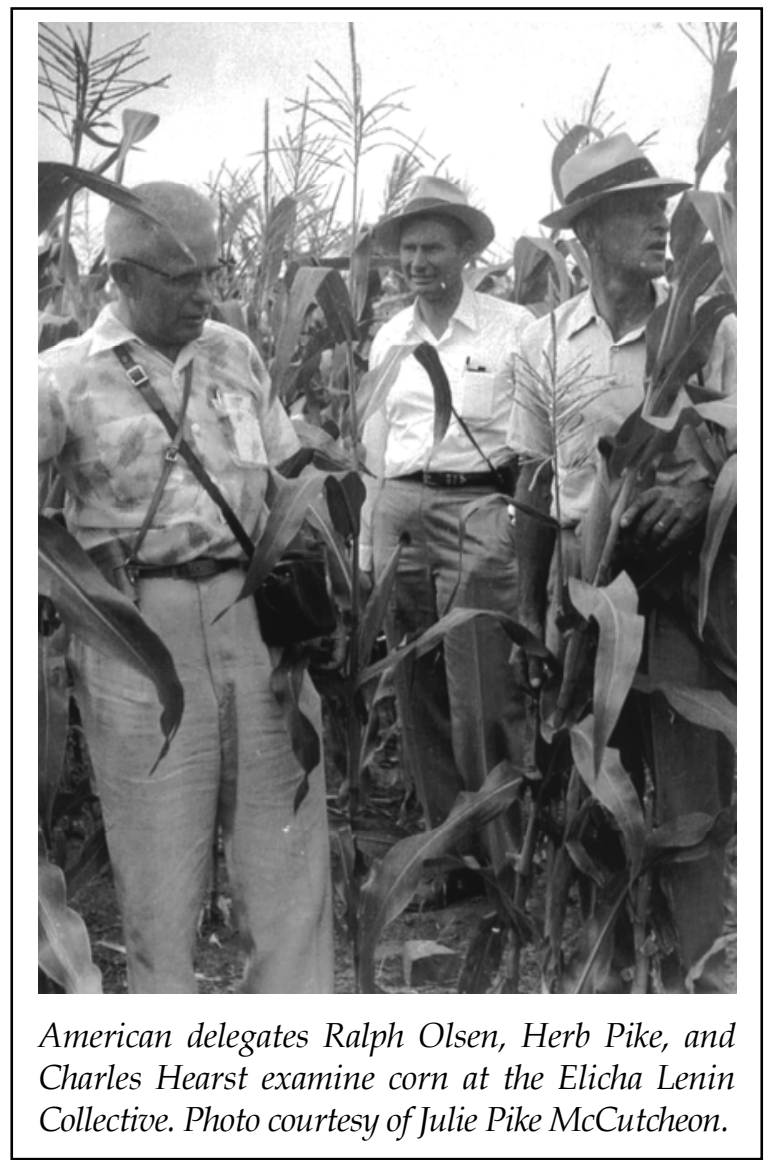

A day after leaving the Soviet Union, Herb Pike shared his experiences in a wide-ranging U.S. News and World Report interview. Despite having just completed six weeks of intense travel, Pike gave detailed and thoughtful responses to a range of questions requiring both observation and opinion. The editors repeatedly asked about the food crisis and war preparations, but Pike did not take the bait. He conceded that the Soviets' diet was monotonous but saw no one undernourished. To Pike, the farms' regimentation was reminiscent of his time in the army: everybody following orders and too many bureaucrats. Impressed with the progress being made, he saw that the people lacked the individual freedoms that "'decadent' Capitalism" 


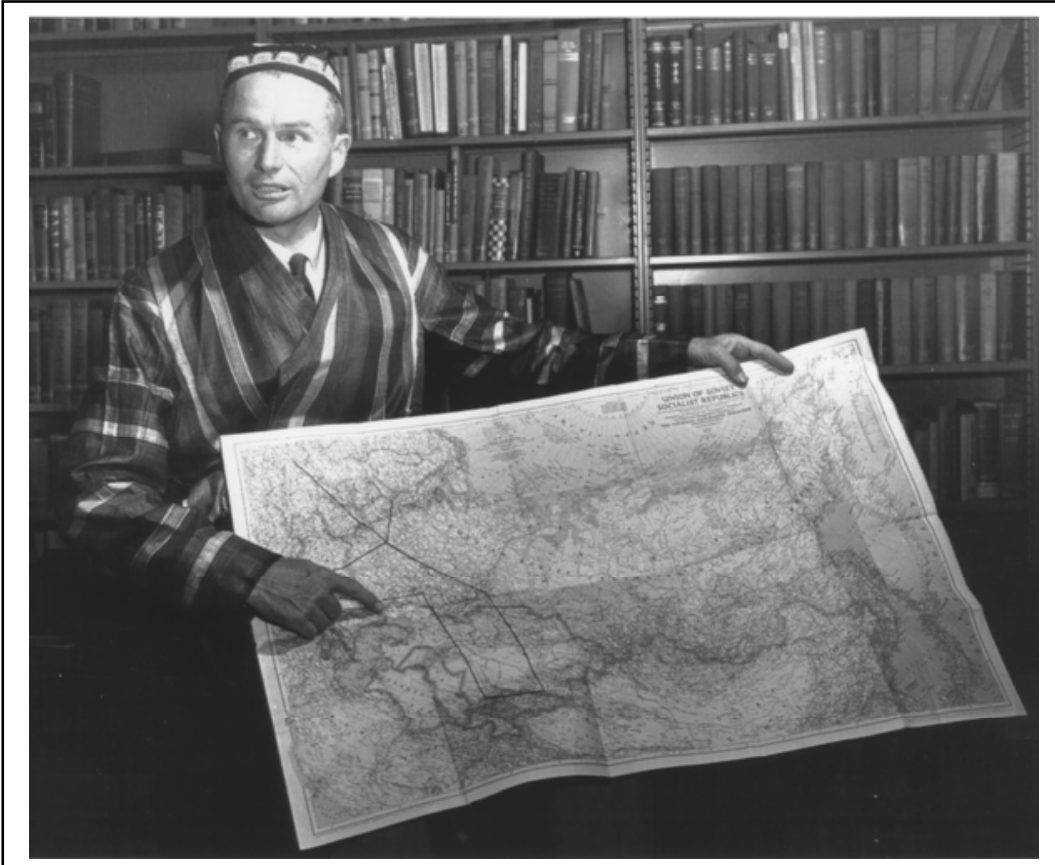

American delegate Herb Pike, dressed in a robe and hat from Uzbekistan, shows the route delegates followed in their tour of the Soviet Union's agricultural regions. Photo courtesy of Julie Pike McCutcheon.

allowed and advised promoting democracy by emphasizing citizens' rights. ${ }^{60}$

Pike wrote about his experiences for the Town Journal and Doane's Agricultural Digest and lectured throughout the Midwest. His views remained consistent over the next several years in speeches and articles. Pike spoke passionately about the need for young people to pursue challenging coursework, particularly in light of a Soviet system that rewarded similar efforts. Two years before the reaction to Sputnik revitalized American science education, Pike urged students to take courses in physics, engineering, and foreign languages. ${ }^{61}$

60. "What's Wrong with Russia's Farms," U.S. News and World Report, 9/2/ 1955, 28; Herb Pike, "Russia was an eye-opener," Town Journal, Sept. 1955, 32$33,88-89$.

61. Pike, "Russia was an eye-opener"; Herb Pike, "Special Report on Farming in Russia," Doane Agricultural Digest, 9/15/1955; Speech transcripts, Pike Papers. 
Like Pike, Lauren Soth immediately reflected on the tour experience in the press. In 12 hard-hitting articles penned in West Berlin and wired to the Des Moines Register, he detailed Soviet agriculture's progress and shortcomings, interactions with Soviets, the country's poor sanitation and safety, lack of consumer goods, women workers, Communism, and thought control. Soth pulled no punches in his close scrutiny of Soviet life. Perhaps to overcome the relative lightheartedness of his original editorial or out of frustration at being denied free movement, he provided detailed assessments that are unrelenting in their criticism: the Soviet workers' paradise as a "cruel jest"; the importance of remembering Soviet brutalities in the face of glad handing; the "paralyzing sameness" of proffered entertainment; "the machinery of party indoctrination and control . . . in fine working order." In later speeches and articles, Soth continued to provide in-depth analyses of Soviet agriculture and life but toned down some of his harsher observations. Outlining shortcomings ranging from inefficiencies and lack of incentives to outdated theories and long-distance decision-making, he emphasized the importance of sharing American know-how and its potential influence on the Soviet system. Soth's tour articles appeared in Chemurgic Digest, The New Republic, and the Illinois Banker, among others. ${ }^{62}$

In 1956 Soth won the Pulitzer Prize for Editorial Writing for his invitation to the Russian farmers. Some correspondents and newspapers continued to voice their disapproval of the exchange, however. Among the backhanded compliments was the Mason City Globe-Gazette's response: "We have a limited enthusiasm for anything which seems to be providing a crutch to history's illest-odored political philosophy, Communism. But that doesn't detract a whit from our pride in the honor Lauren Soth has brought to our state." 63

62. Lauren K. Soth, “The Soviet Drive for Better Food," Chemurgic Digest, November 1955, 4-5; Lauren K. Soth, "Farm Life in the USSR," The New Republic, 9/26/1955, 17-20; Lauren K. Soth, "Americans See Russian Farms," Illinois Banker, May 1956, 12-13.

63. "Honor for an Iowan," Mason City Globe-Gazette, undated news clipping, Soth Papers. 
Broadcasting from London on the return trip to the United States, Herb Plambeck reported that the group had "a million memories" of the "fast, rugged, sleep-defying trip." He took seriously his role as a representative of farm reporters, offering films and broadcasts to stations around the country on his return. By December 1955, Plambeck reported, he had shared tapes with more than a thousand radio stations, given 85 talks to an estimated 45,000 listeners, and written articles for Kiwanis International and various farm publications. ${ }^{64}$

AS THE AMERICANS toured Moscow, Eisenhower met in Geneva with British Prime Minister Anthony Eden, French Prime Minister Edgar Faure, and Soviet Premier Nikolai Bulganin; Khrushchev was part of the Soviet entourage, his active presence signaling his growing importance. On the agenda were German reunification, disarmament, atomic energy, and cultural exchanges. Propelled by the "spirit of Geneva," the leaders debated the issues to be ironed out by their foreign ministers in an upcoming meeting. In October and November they reconvened in Geneva. Again the subject of East-West contacts was raised. On October 31 Secretary of State Dulles announced that the United States would no longer require special validation to travel to the Soviet Union; with a passport and visa, Americans were free to visit behind the Iron Curtain. A day later the Soviets proposed a second agricultural tour of the United States. Because the Soviets knew that it would be impossible for the U.S. government to organize a second tour in one week as proposed, State Department officials believed that the Soviets wanted to make the U.S. government appear to be "blocking popular demands" by U.S. citizens for increased exchanges. The State Department thus instructed the Geneva contingent to use the request to illustrate the "difficulties of hit and miss programs." 65

For the many Americans who volunteered their services or suggested similar exchanges, the 1955 agricultural delegations offered hope that peaceful coexistence could be a reality as they

64. Herb Plambeck, “To Whoever May Be Interested," n.d., Plambeck Papers. 65. Memo, State Dept. to the American Embassy, Geneva, 11/2/1955, NA. With the end to U.S. controls on American travel, the trickle of tourists to the Soviet Union increased to 2,000 by 1956. Levine, Travel Guide to Russia, 13. 
connected with Soviets through professional interests. Others were simply intrigued. Physicians, plumbers, businessmen, chambers of commerce, and Tupperware Party hostesses proposed trips before controls were lifted. Among those who traveled to the Soviet Union in the fall of 1955 was Roswell Garst of Coon Rapids. First Deputy Minister of Agriculture Vladimir M. Matskevich, who had headed the Russian delegation to the United States, had been impressed with Garst's 2,300-acre farm and invited him to visit the Soviet Union. Garst sold hybrid corn seed to the Soviets and met with Khrushchev, who would later visit Garst's farm in 1959.66

Horace Davis, the embassy attaché, believed that the information gathered on farms and machine tractor stations was "highly significant," although "knowledge of the overall" agricultural system remained small. ${ }^{67}$ In six detailed confidential reports released over the next eight months, he reviewed his and the delegates' many pages of notes. Both Davis and the embassy praised the caliber of the American group. Among the delegation's successes was their "favorable impression" on Soviets and "superb job selling America and the American way of life." Weighing the pros and cons, the embassy concluded that the exchange had been worthwhile from an American standpoint. ${ }^{68}$ The delegation had seen regions that had been closed to most Westerners since World War II.

While the State Department shared Davis's reports with the FBI and CIA, anecdotal evidence suggests that the CIA may have taken an active role in intelligence gathering during the tour. NBC reporter Irving R. Levine always suspected that there was at least one CIA plant in the group. ${ }^{69}$ A 1956 letter from Marion

66. Curiously, Khrushchev's son ignored the July-August 1955 American agricultural delegation in a 1999 American Heritage article and references only Garth's October 1955 visit to the Soviet Union as the U.S. response to Soth's editorial. See Sergei Khrushchev, "The Cold War Through the Looking Glass," American Heritage 50, no. 6 (1999), 34-38, 40, 42-46, 49-50. On Khrushchev's vist to Garst's farm, see Stephen J. Frese, "Comrade Khrushchev and Farmer Garst: Summit in an Iowa Cornfield," Iowa Heritage Illustrated 85 (2004), 146-53.

67. Memorandum, Horace J. Davis to Chargé d'Affaires, 9/21/1955, NA.

68. Foreign Service Despatch from the American Embassy, Moscow, to the State Dept., 3/25/1956, NA.

69. Irving R. Levine, “Russia I," unpublished article, 2001, author's collection. 
Steddom to the Internal Revenue Service may confirm his assumption. Steddom asked the IRS to allow a tax deduction for costs incurred as a delegate, citing his contributions to his country and the losses he took during harvest season. Although he could not divulge the details, he wrote that he and others were asked to collect vegetation "daily for later chemical analysis in order to determine the location of the places where Russia was testing the atom bomb."70 A recollection by Pike's daughter may corroborate Steddom's story. Nine years old in 1955, she distinctly recalls that before her father left, an important visitor from Washington arrived at their Whiting farmhouse in a twoseat convertible - a rare sight in the rural town of $700-$ for a private meeting with her father. Later she learned that the visitor had asked him to collect for analysis flower samples from the bouquets presented at each farm..$^{71}$

A first-person CIA report on the delegation's observations, dated September 23, 1955, was delivered to the White House on November 4.72 Although the report is anonymous, the opening paragraphs nearly match the lead of Gale Johnson's September 4 New York Times magazine article. Whether someone plagiarized Johnson's article or he wrote the report himself is unknown. ${ }^{73}$

70. [Marion Steddom] to the IRS, 7/26/1956, Steddom Papers. FOIA requests to the CIA and IRS to confirm Steddom's claim have thus far been unsuccessful. However, a recently released document indicates early CIA interest in the delegation. Memorandum of Conversation, 3/14/1955, NA.

71. Julie Pike McCutcheon, telephone interview with author, 8/1/2011.

72. "Observations on Agriculture in the Soviet Union," 9/23/1955, attachment to memorandum from [redacted] to Gabriel Hauge, administrative assistant to the president, White House Office, Dwight D. Eisenhower Records as President, White House Central Files, 1953-61, CREST database, NA.

73. In March Johnson had broadcast a "pessimistic appraisal" of Khrushchev's corn-planting program for Radio Liberty, an anti-Communist radio station sponsored by the American Committee for Liberation from Bolshevism; a 1971 U.S. Senate investigation confirmed that the committee had been covertly funded by the CIA for the past 18 years. New York Times, 3/14/1955, 4; ibid., $1 / 24 / 1971,1$. The CIA report also includes paragraphs identical to those in another article by Johnson: "Observations on the Economy of the U.S.S.R," Journal of Political Economy 64 (1956), 185-211. Johnson continued teaching at the University of Chicago until 1998, authoring more than 300 books and articles. For Johnson's contributions to economics, see John M. Antle and Daniel A. Sumner, eds., The Economics of Agriculture, vol. 1, Selected Papers of D. Gale Johnson, and vol. 2, Papers in Honor of D. Gale Johnson (Chicago, 1996). 
Ultimately, the delegation's importance rests not with the specific information collected but with the insights delegates provided to a curious, if nervous, American public. Like themselves, the Soviets met by the delegates desired peace and personal interactions. In speeches throughout the country, the Iowa delegates provided a new awareness of the Soviet Union for Americans hungry for reassurance as well as facts. The delegates' assurances that Russians did not have horns helped spark a growing interest in what was behind the Iron Curtain, and their tour proved an early step in establishing East-West contacts. Three years later, in 1958, the United States and the Soviet Union signed the Lacy-Zaroubin Agreement, which formally covered media, scientific, cultural, and tourist exchanges.

Analyzing the exchanges between U.S. and Soviet scientists, performers, and educators that followed Stalin's death, historian Yale Richmond writes that such contacts must be given credit for contributing to the collapse of the Soviet Union. ${ }^{74}$ As one of the earliest exchanges, the 1955 American agricultural delegation to the Soviet Union helped pave the way for future contacts and formal agreements between the two nations. 